\title{
Effect of Ocimum basilicum oil on the Consistency of Tallaga Cheese in Full-fat and Low-fat during Storage
}

\section{By}

Yonis, A.A.M., Rasha

Home Economics Dept.

Faculty of Specific Education

Mansoura University, Egypt.
Rasha, M., Nagib

Home Economics Dept.

Faculty of Specific Education

Mansoura University, Egypt.

\section{Lobna, A. I., Abo Nishouk}

Home Economics Dept.

Faculty of Specific Education

Mansoura University, Egypt. 
Effect of Ocimum basilicum oil on the Consistency of Tallaga Cheese

in Full-fat and Low-fat during Storage

Yonis, A.A.M., Rasha *

Rasha, M., Nagib*

\section{Lobna, A. I., Abo Nishouk*}

\section{Abstract}

This study was conducted to investigate the effect of different levels of basil oil on chemical composition and sensory characteristics of full-fat and low-fat Tallaga cheese.. Both full-fat and low-fat buffalo's milk curd was divided into four equal portions. One batch had no basil oil as a control. The latter batches were fortified with oil at the rate of $0.05,0.10$ and $0.15 \%$. The resultant cheese samples were stored at $6 \pm 1{ }^{\circ} \mathrm{C}$ for 30 days.Chemical and sensory evaluations were carried out for the cheese samples at zero, 10 , 20 and 30 days. The results identification of O. Basilicum oil compounds using GC-MS with a flame ionization detector analysis showed that the main components were methyl chavicole $(71.30 \%)$ followed by cineole (11.70\%), linalool (11.37\%), methylengenol $(2.60 \%)$ and caryophyllene $(0.71 \%)$. Chemical and sensory evaluations were carried out for the cheese samples at zero, 10, 20 and 30 days. The results indicated that significant variations were found in the titratable acidity, fat, S.N. and thiobarbituri acid among the control and the treated cheese samples, the highest titratable acidity was for the control cheese while the lowest one was for the cheese sample with $0.15 \%$ basil oil. No significant differences were observed in the fat contents of the different treatments. The storage period had significant effect on the chemical composition of the cheese samples. As the storage period advanced the titratable acidity, soluble nitrogen andthiobarbituri acid increased towards the end of the storage period. Sensory evaluation of cheese showed the flavor of basil flavored cheeses were higher than plain cheese during the storage period. There were no significant differences in

${ }^{*}$ Home Economics Dept. Faculty of Specific Education Mansoura University, Egypt. 
the cheese's appearance nor in the chemical composition of plain and basil cheeses.

\section{INTRODUCTION}

White soft cheese is one of Egypt's most popular delicious cheeses. Many white soft cheese varieties depend on the manufacturing technique, the percentage of salt and many other factors. Tallaga cheese was produced using low salt percentage and stored in the refrigerator at $\left(5-7^{\circ} \mathrm{C}\right.$ ) (AbouDonia, 1986). It is one of the most popular local soft cheeses in Egypt, favored by all socioeconomic classes due to its nutritional value, good taste, clean nice creamy low salty taste with a spreadable smooth soft body and predominantly ready for consumption at refrigerator temperature within one month (El-Kholy, 2016).

One of the food industry's main objectives is to produce good sensory acceptance goods. A brand should fulfill consumer expectations to achieve this goal and overcome strong competition. In this context, the use of essential oils in cheese production could be a promising option for dairy industries, as customers view cheeses favorably (Kresic et al.,2010).

Essential oils are complex mixtures of various chemical compounds, most of which have been classified as safe extracts (GRAS). Such oils have impressive antioxidant and antimicrobial capacity and have the potential to be used as a biopreservative in the food industry to avoid spoilage and prolong the consumer shelf life (Burt, 2004).

It is important to use essential oil extracts as food flavoring agents an $\mathrm{d}$ as biopreservatives.

In addition, essential oil extracts may have potential medical uses as they have had a strong antioxidant activity that can play a role in reducing th e risk of certain chronic diseases (El-Nawawyet al. 1998).

OcimumbasilicumL. Considered promising essential oil crops, the essential oil composition (and aroma) of basil cultivars varies widely on the international market. The essential basil oil has a pleasant aroma and is known to have anti-microbial, antioxidants. (Bozinet al., 2006) and insecticidal (Aslan, et al., 2004) activities and has been used traditionally as 
a medicinal herb (Simon, et al., 1999). Basil was used to treat fevers, congestion of the throat and stomachache (Omidbeigi, 2000). Basil is also used for pharmaceutical and cosmetic prepa-ration due to the high content of phenolic compounds found in all plants, which are well known phytochemical molecules and act as antioxidants to prevent heart disease. (Simon, et al., 1984) reducing inflammation, (Mohanlal, et al., 2012) reduce cancer incidence (Sawadogo, et al., 2012) and diabetes, (Scalbert, et al., 2005) in addition to reducing mutagenesis levels in human cells Pedreschi, et al., 2006).

An area of future interest is the relationship between food additives a nd nutrients within the food matrix. Consequently, this study's main objectiv e was to examine the influence of various levels of O.Basilicum oil on the soft cheese tallaga's chemical composition and sensory characteristics.

\section{MATERIALS AND METHODS}

The buffaloes'milk used in this study was standardized to $6 \%$ (for full- fat cheese) and 3\% (for low-fat cheese). It was collected from a local farm in Mansoura, Egypt.Salt "Sodium chloride ", produced by EL-Nasr Saline's Co., Alex. Rennet, Animal liquid rennet from local Market.

\section{Tallaga cheese production:}

Tallaga cheese production was carried out with some adjustment according to El-Kholyet al. (2016). Briefly, both fresh buffalo milk (3\% and $6 \%$ fat) was heated for 15 seconds at $80^{\circ} \mathrm{C}$ and then instantly cooled to $37^{\circ}$ C. Sodium chloride and rennet are applied respectively at a ratio of $4 \%$ and $0.1 \%(\mathrm{w} / \mathrm{v})$.

Then for 10 minutes the full-fat and low-fat milk was mixed and left for coagulation. The coagulated full-fat and low-fat milk was cut for whey separation after 2-3 hours; then the each drained curds were divided into four sections, the first treatment being the control without adding $\mathrm{O}$. Basilicum oil. To the second third and fourth parts $0.05 \%, 0.10 \%$ and 0.15 $\%$ O. Basilicum oil concentrations were added respectively. The curd of each treatment was transferred to a wooden mould lined with a clean cloth and pressed by a heavy weight of about $2 \mathrm{Kg}$ for 6 hours. Thereafter the 
cheese was removed from the mould and cut into small cubes of about $5 \times 5$ $\times 5 \mathrm{~cm}$ approximately. The whey was collected in a separate container boiled for five minutes and used for preservation of the particular cheese. The cheese samples were packed into triplicate plastic containers of 400 grams capacity each containing $200 \mathrm{ml}$ of the appropriate boiled whey. The containers were tightly closed and sealed with cellophane tapes around the cover. The containers were stored at refrigerator temperature $(6 \pm 1 \mathrm{oC})$ for 30 days. Chemical analysis and sensory evaluation were carried out at zero, 10, 20 and 30 days interval.

\section{Extraction of peppermint essential oil:}

Fresh sweet basil (Ocimumbasilicum) leaves, purchased from a local market in Egypt were charged into a 5-liter round-bottomed flask and mixed with distilled water at a ratio of 1:10 (plant material to water) followed by hydro-distillation using a Clevenger-type apparatus for $2.5 \mathrm{~h}$. At the end of distillation, the separated essential oil was collected from the side arm of the apparatus, dried over anhydrous sodium sulfate and stored in dark glass bottles at $-4^{\circ} \mathrm{C}$ until it was used in the manufacture of the flavored cheese. The distillation procedure was repeated several times with a new fresh charge of sweet basil leaves each time until the required amount of $\mathrm{O}$. Basilicum essential oil had been collected.

\section{Chromatographic analyses of Ocimumbasilicum oil:}

Analysis of O. Basilicum essential oil GC was performed using a Perkin Elmer Auto System XL model equipped with a flame ionization detector (FID). A fused silica capillary column ZB-5 (60 $\mathrm{m} \times 0.32 \mathrm{~mm}$ i.d.) was used. The oven temperature was programmed from $50^{\circ} \mathrm{C}$ to $240^{\circ} \mathrm{C}$ at a rate of $3^{\circ} \mathrm{C} / \mathrm{min}$. Helium was used as the carrier gas, at a flow rate 1.1 $\mathrm{ml} / \mathrm{min}$.

The injector and detector temperatures were $230^{\circ} \mathrm{C}$ and $250^{\circ} \mathrm{C}$. The retention indices (kovats index) of the separated volatile compounds were calculated with reference to the retention time of the n-paraffin (C6-C20) series. The isolated peaks were identified by comparison with those of authentic compounds. 


\section{Cheese chemical analysis}

White soft cheese samples were chemically analyzed according to AOAC (2000) for fat, total protein, ash and soluble nitrogen contents. Acidity as lactic acid was determined by the titration method with $1 / 9 \mathrm{~N}$ $\mathrm{NaOH}$, according to Ling's method (1963). Thiobarbituric acid was estimated according to Keeny (1971).

\section{Sensory properties of cheese}

The sensory properties of the cheese samples after0, 10, 20 and 30 weeks of cold storage at $6 \pm 1{ }^{\circ} \mathrm{C}$ were evaluated according to Pappas et al. (1996). Cheese was assessed by 15 panelists from the staff of the Department with a maximum score points of 60 points for flavor, body and texture (30 points) and 10 points for the cheese's appearance.

\section{Statistical analysis}

Statistical analysis of the results obtained was performed using the Statistical Analysis System (SAS) using the ANOVA procedure for analysis of variance, and the general linear model (GLM) procedure for SAS software (SAS, 1990).

\section{RESULTS AND DISCUSSION}

\section{Determination of Ocimumbasilicumoils chemical composition}

Table 1 summarizes the findings of the quantitative and qualitative st udy of the constituents of $\mathrm{O}$. basilicum essential oils:

Our analysis showed that methyl chavicole (71.30 percent) followed by cineole (11.70 percent), linalool (11.37 percent), methylengenol (2.60 per cent) and caryophyllene ( 0.71 percent) were the main constituents in the ess ential oil. This finding is in line with Shiraziet al., (2014). 
- Effect of Ocimum basilicum oil on the Consistency of Tallaga Cheese in Full-fat and Low-fat

Table(1): Chemical composition of Ocimumbasilicumleaves oil:

\begin{tabular}{|c|c|c|}
\hline Compounds & Retention time (min) & Area $\%$ \\
\hline$\alpha$-Pinene & $\varepsilon, \varepsilon 7 \varepsilon$ & $\cdot, 11$ \\
\hline$\beta$ - Pinene & 0,079 &., $1 \varepsilon$ \\
\hline Limonene & V,rrq & $\cdot, \cdot V$ \\
\hline 1.8- Cineole & $v, 0.9$ & $11, v$. \\
\hline (z)- Sabinene hydrate & 17,914 & $\cdot, r q$ \\
\hline Linalool & MA,rY. & II,rV \\
\hline Caryophllene & $r \cdot v \leqslant r$ & $\cdot, V_{1}$ \\
\hline Methyl chavicol & rr,ITV & vi,r. \\
\hline Camphor & rr,q1r & $\cdot r \varepsilon$ \\
\hline Terpineol & ro,r.o & $\cdot, Y q$ \\
\hline Cadinene & rV,0T. & $\cdot r_{1}$ \\
\hline$\beta$ - Bisabolene & YN,THו & $\cdot, 1$ \\
\hline (z)- Nerolidol & $r \varepsilon, 01 V$ & $\cdot r_{1}$ \\
\hline Methylengenol & ro, I r & $r, T$. \\
\hline Spathulenol & $r v, \cdot \xi 0$ & $\cdot, 1$. \\
\hline Eugenol & $r 9,700$ & $\cdot, 10$ \\
\hline
\end{tabular}

Effect of processing time on Tallaga soft cheese's chemical composit ion and sensory properties

\section{Titratable acidity:}

Results in Fig.( 1 ) explained that fortified full-fat tallaga cheese with basil oils of different grades resulted in a significant increase in acidity during the storage period. Such an increase in titrable acidity can be caused by stimulating the growth of lactic acid bacteria and eventually participating in the production of lactic acid.

Also, the data shown in fig. (2) summarize improvements in low-fat tallaga cheese acidity during processing. In particular, it was apparent that for all therapies, the acidity rose slowly.These results are in accordance with those reported by Gamalet al., (2012) . 


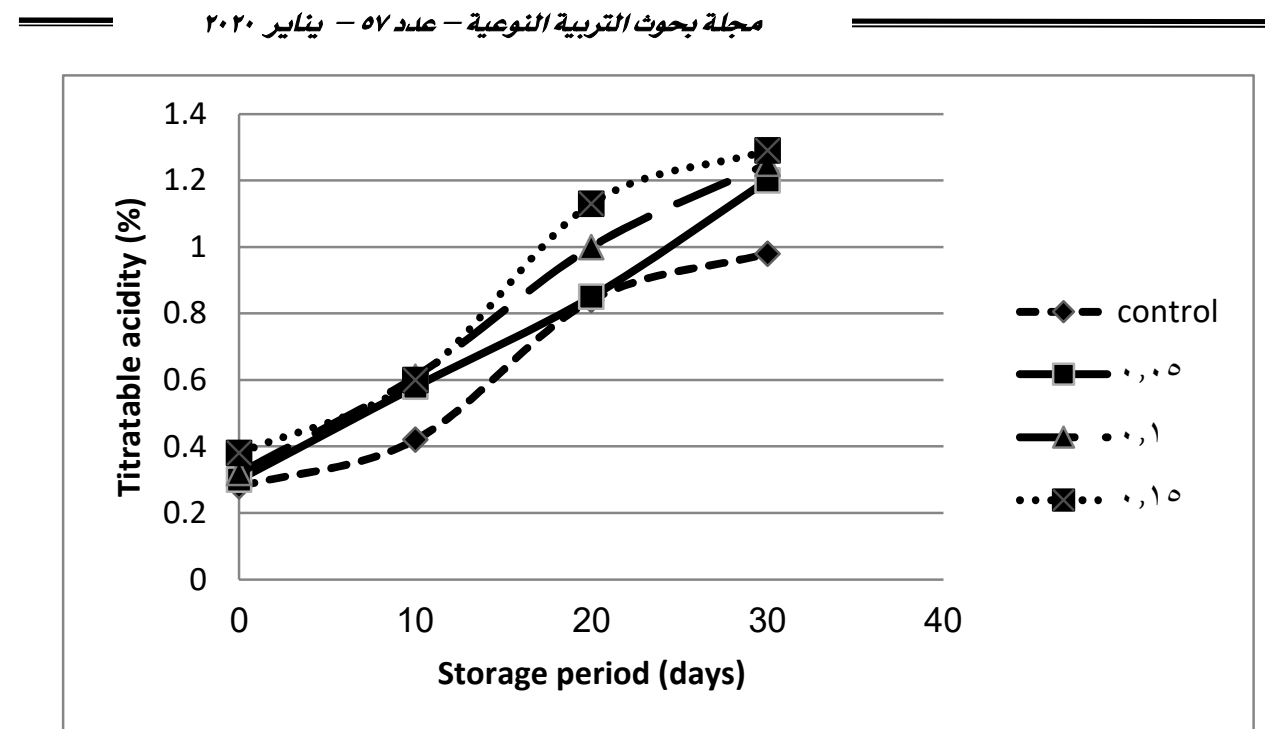

Figure 1: Titratable acidity (\%) of fortified full-fat Tallaga cheese with basil oil.

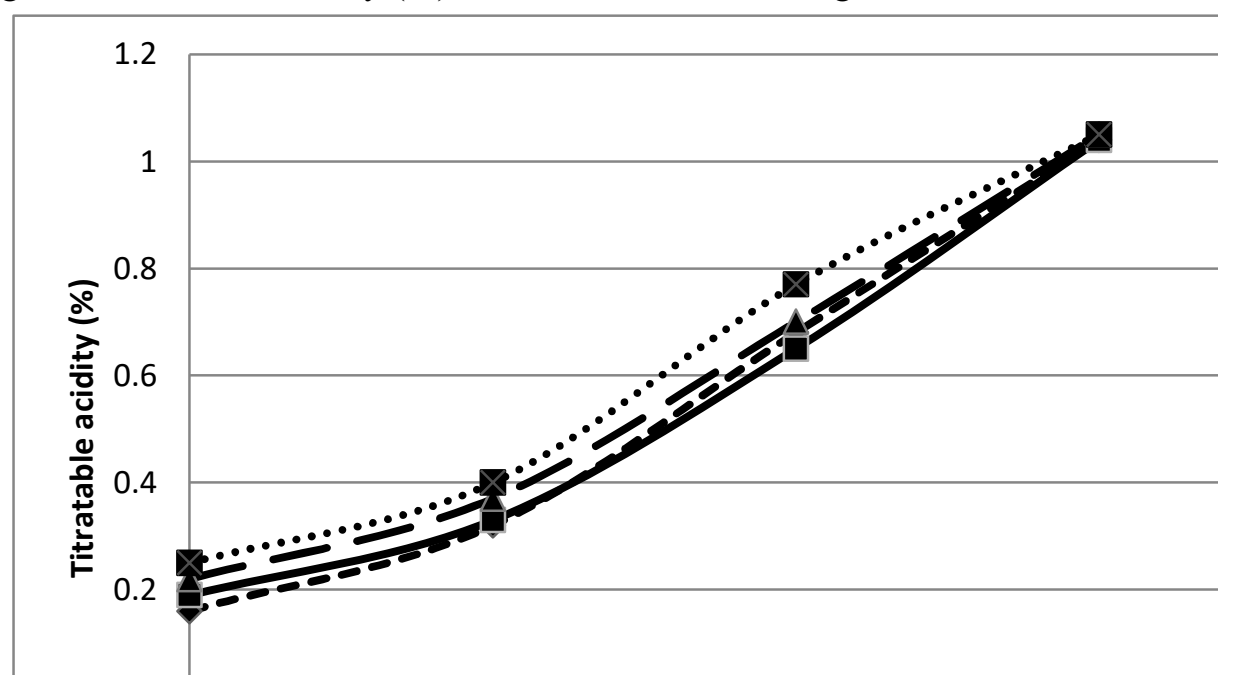

Figure 2: Titratable acidity (\%) of fortified low-fat Tallaga cheese with basil oil.

Fat content of all samples of fat tallaga cheese fortified with basil was increased slightly during storage periods up to 30 days (fig.3). This rise in fat content may be due to a reduction in moisture content throughout the storage period. These findings are nearly in line with those reported by Kamaly, (1978) and Gamalet al. (2012). 
While for all low-fat fortified tallaga cheese samples with basil, fat content slowly and gradually decreased over the prolonged storage period (fig.4).Such findings are in accordance with Abo-Donia (2005) who found that the fat content in cheese was not influenced by the herbs used and attributed the changes in the fat content to the changes that occurred during the storage process. Fodaet al., (2006) stated that neither herb form nor concentration of herbal cheeses had a significant effect on the fat content of herbal cheeses, but it had a significant effect to prolong the storage time. Ayar, (2002) identified some variations in fat and protein values based on total cheese solids.

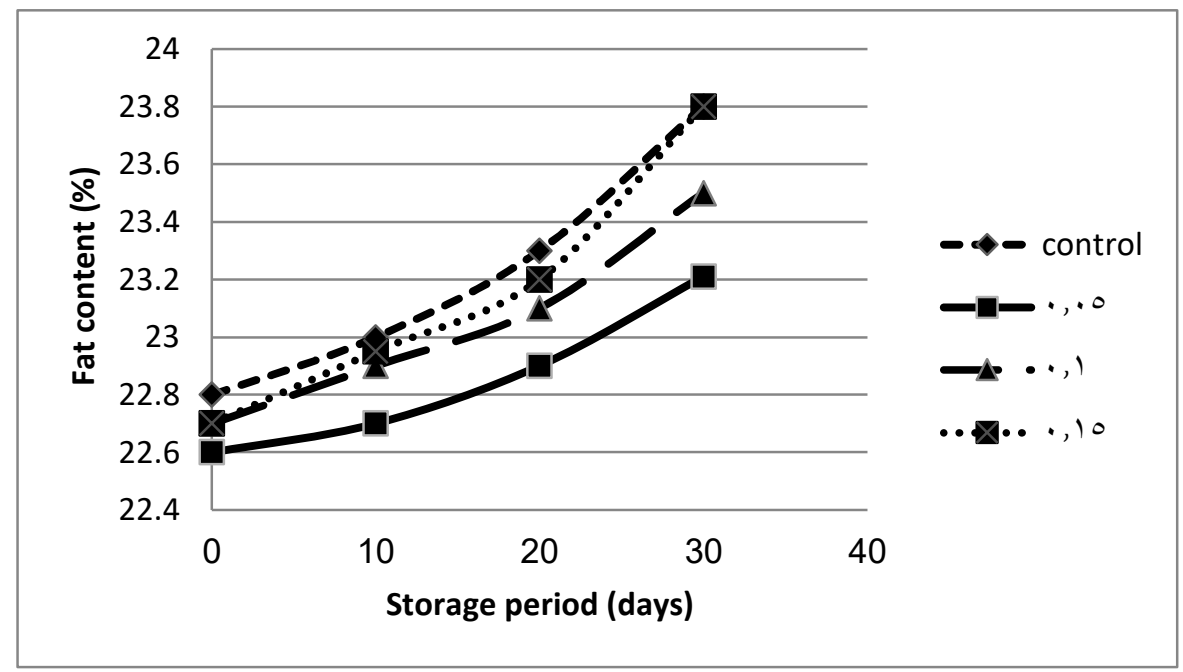

Figure 3: Fat content (\%) of fortified full fat Tallaga cheese with basil oil. 


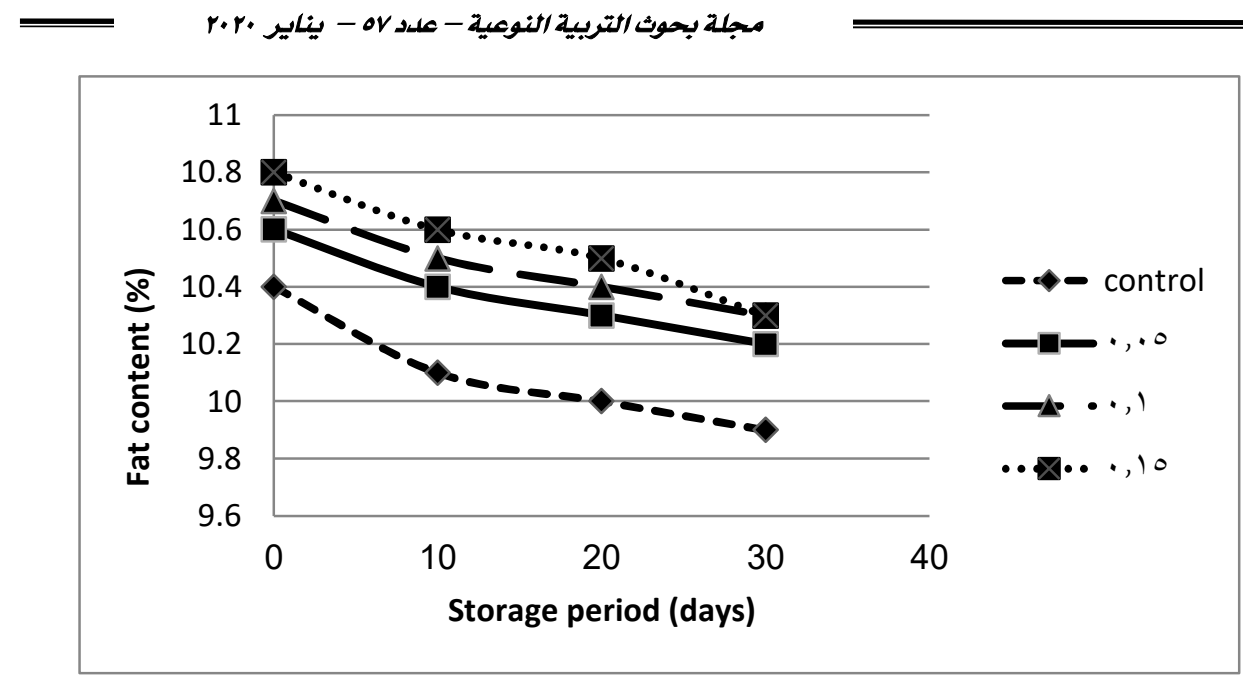

Figure 4: Fat content (\%) of fortified low fat Tallaga cheese with basil oil.

\section{Soluble nitrogen content :}

The fortified full-fat tallaga cheese's soluble nitrogen slightly decreased with an increase in the percentage of added basil (figure 5). While the soluble nitrogen marked by increased up to 30 days as a result of proteolytic activity of proteinases enzymes in cheese with extended processing of fortified cheese samples. This result is consistent with Fodaet al., (2008) coverage.In the meantime, (fig.6) shows that the soluble nitrogen content of low-fat tallaga cheese fortified with various basil oil levels is not significantly different. Interestingly, with increased storage time, there was a strong increase for soluble nitrogen content.Such findings are in agreement with Tarakci and Kucukoner (2006), who reported substantial increases in soluble nitrogen in herbal cheeses throughout the maturation period. Costableet al., (2007) also stated that the ripening period had a greater influence on cheese proteolysis than any other assayed parameter and attributed this to the breakdown of $\alpha$-s and $\beta$-caseins as evidenced by electrophoresis. 
- Effect of Ocimum basilicum oil on the Consistency of Tallaga Cheese in Full-fat and Low-fat

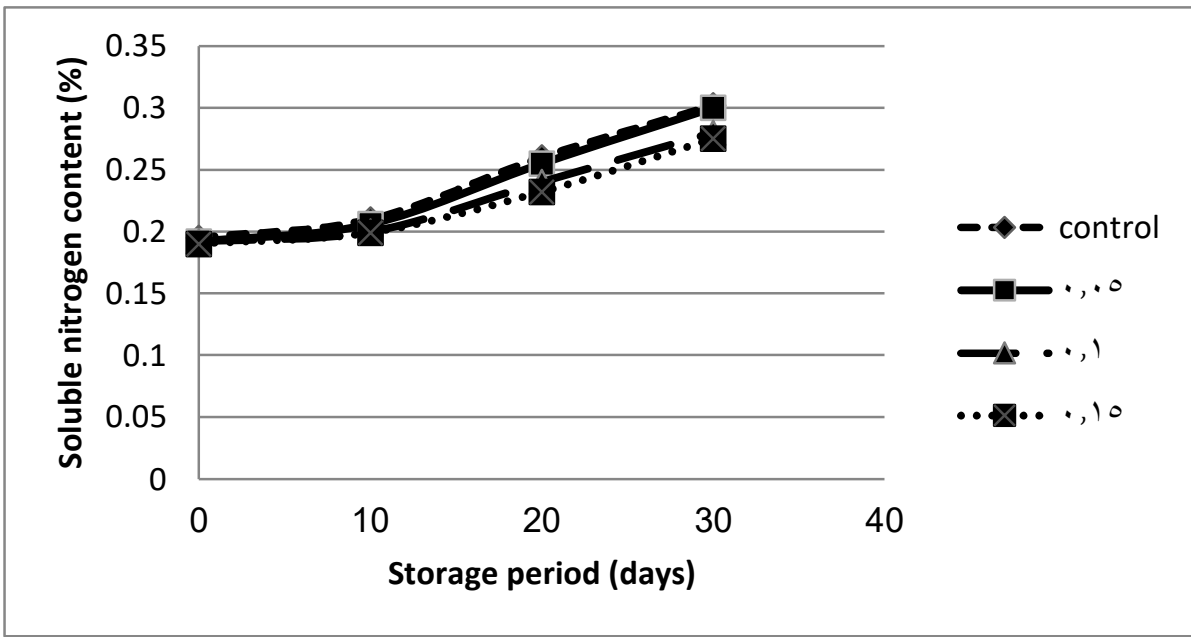

Figure 5: Soluble nitrogen content (\%) of fortified full-fat Tallaga cheese with basil oil.

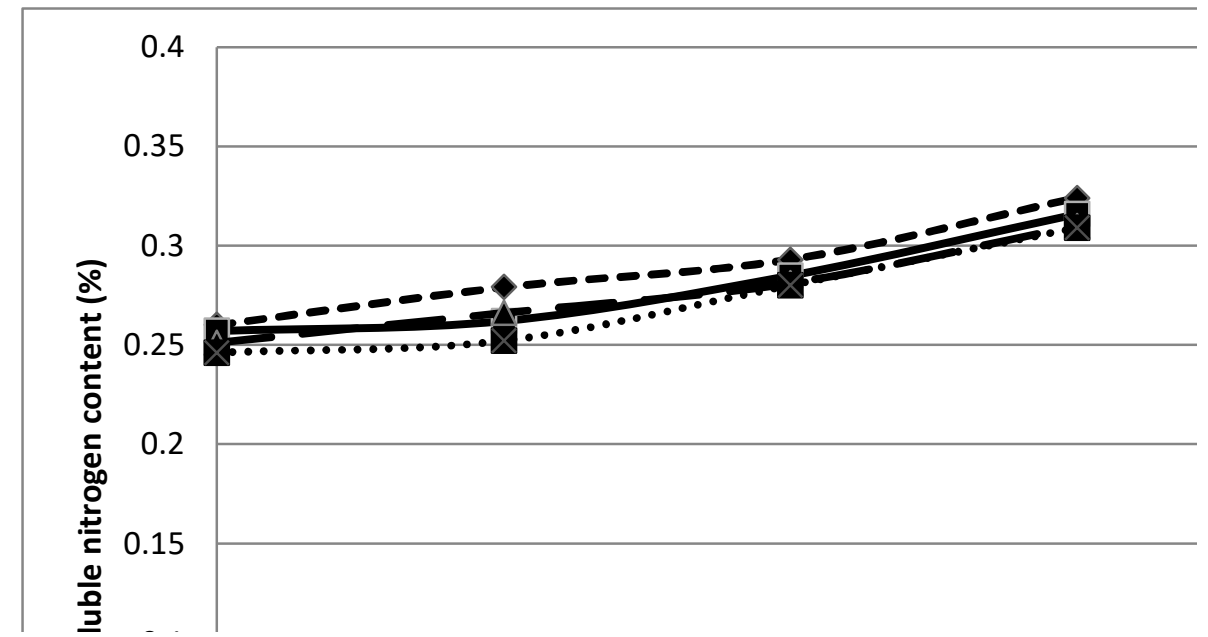

Figure 6: Soluble nitrogen content (\%) of fortified low fat Tallaga cheese with basil oil.

\section{Thiobarbituric acid-reactive substances (TBARS):}

Typically oxidation signal values of thiobarituric acid-reactive substances (TBARS). The antioxidant effect of basil oils as calculated by the TBARS values of lipid oxidation fortified full-fat $T$

allaga cheese is shown in Fig. (7). The TBARS values decreased significantly as the amount of fortifying oils in fortified Tallaga cheese 


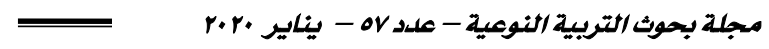

increased. This means basil oils have a slight effect on oxidized flavor induction. On the other hand, as the storage time proceeded, the TBARS values of all cheese samples increased.

Such findings could be classifying the influence of basil oil during the processing cycle and microorganism behavior on the stimulating effect on fat hydrolysis.

Fortifying low-fat Tallaga cheese with basil oils induced a daily decrease in TBARS values (Fig.8) compared to the control cheese up to 30days of processing. The initial TBARS concentrations in all treated cheeses during the storage period were lower than that of the test. The TBARS values of all treated cheese samples increased slightly, while the control sample TBARS values increased significantly.

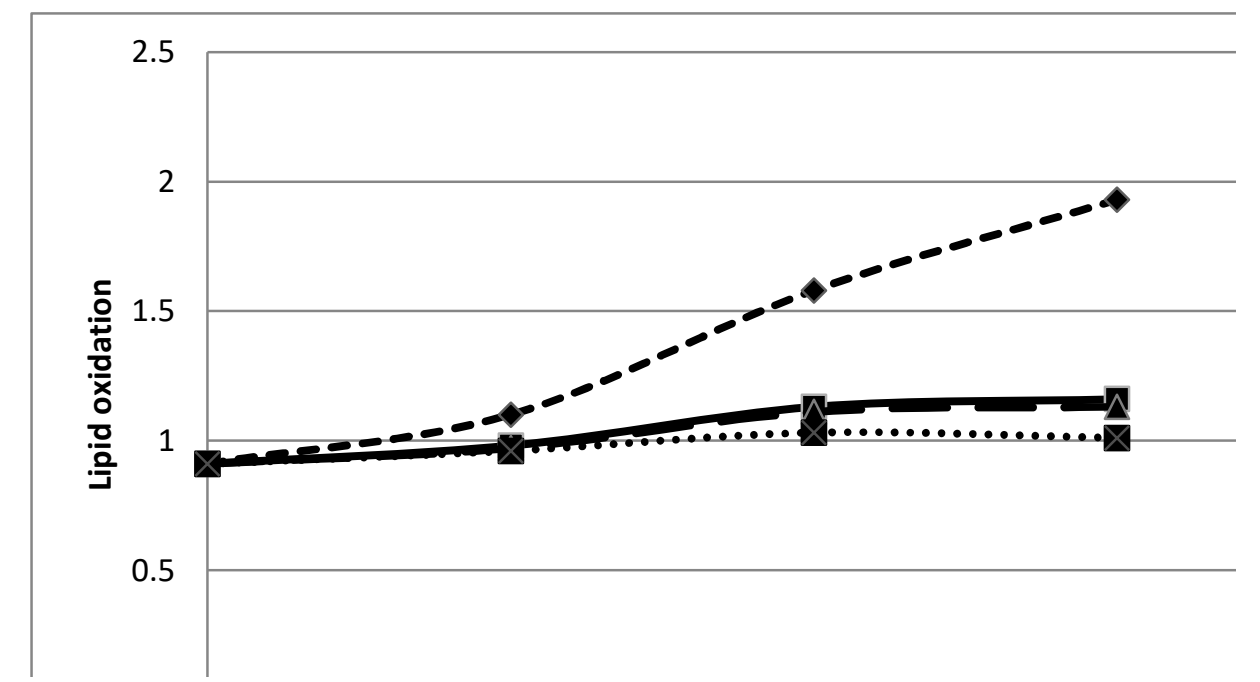

Figure 7:Lipid oxidation (thiobarbituric acid - reactive substances [TBARS]) values of fortified full-fat Tallaga cheese with basiloil . 


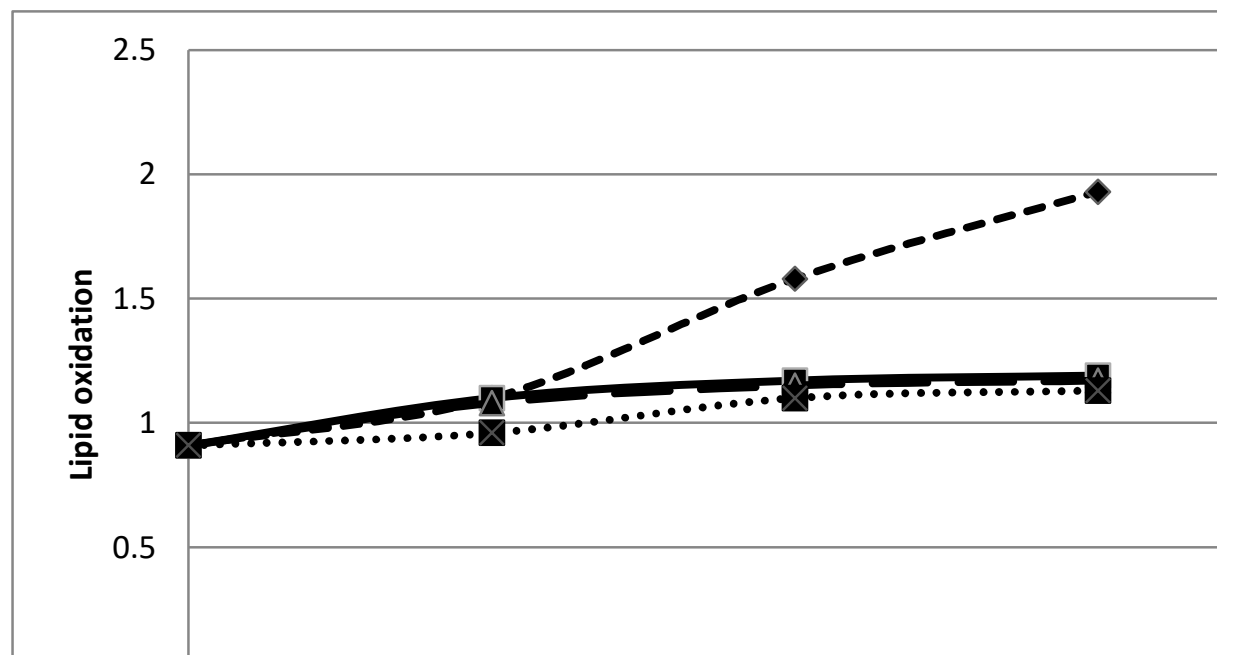

Figure 8:Lipid oxidation (thiobarbituric acid - reactive substances [TBARS]) values of fortified low-fat Tallaga cheese with basil oil.

\section{Sensory assessment during processing of the fortified Tallaga cheese:}

Full-fat and low-fat Tallaga cheese fortified with different basil oils ratio was sensory evaluated at $(6 \pm 1$ oC) for 30 days when fresh and along during processing. The judging score reported that cheese appearances had slightly lower scores than the control, especially in the samples treated with higher levels of additives.

The presence of cheese decreased for all specimens as the processing period continued. With regard to flavor ratings, as the storage cycle progressed, the taste of all cheese samples decreased.

With regard to the resulting cheese's body and texture ratings, it could be said that the addition of basil oils up to 0.1 percent enhanced the consistency of the cheese, then the scores slightly decreased.In addition, cheese texture scores behaved similarly to cheese appearance and flavor characteristics as it slowly decreased by increasing processing time.

A look at the total scores (Figures.9 and 10)It was obvious that, when fresh and stored in the refrigerator for 30 days, the addition of additives up to $0.10 \%$ produced cheese with higher sensory acceptability than the order. 
As a result, basil oils could be used in the processing of Tallaga cheese to produce widely accepted and safer cheese.

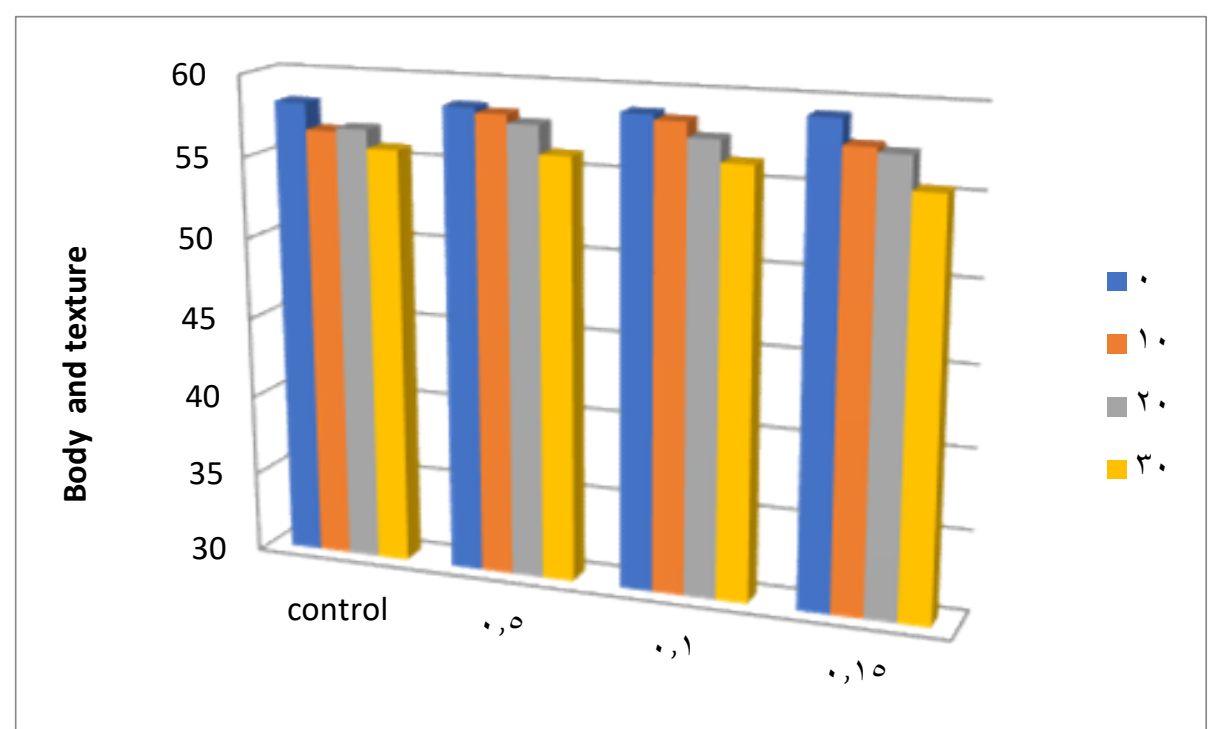

Figure 9: Effect of storage on body and texture of fortified of full-fat Tallaga cheese with basiloil .

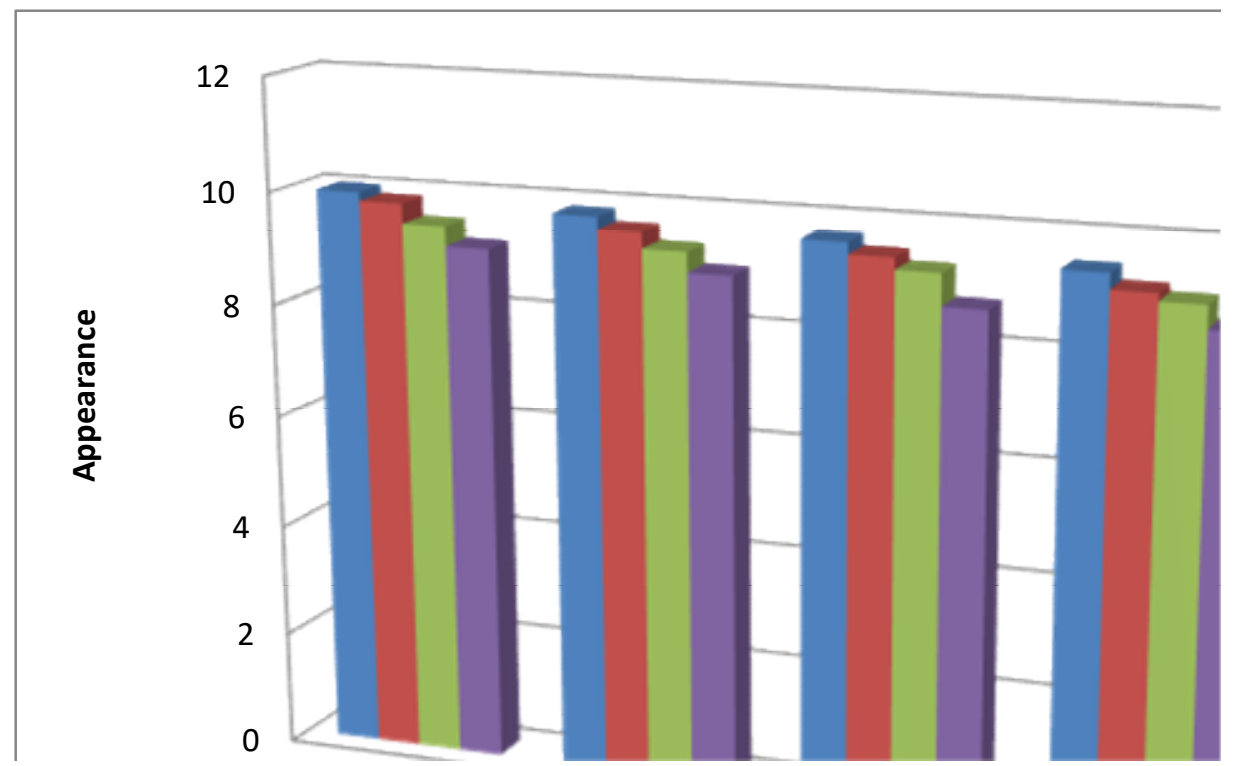

Figure 10: Effect of storage on appearance of fortified of low-fat Tallaga cheese with basil oil. 
= Effect of Ocimum basilicum oil on the Consistency of Tallaga Cheese in Full-fat and Low-fat

\section{References}

- AbouDonia, S. A. 1986.Cecent developments in Egyptian Domiati cheese research: An Overview. Egypt. J. Dairy Sci., 35: 1-14.

- Abou-Donia, S.A. 2005. Egyption adopted plastic curd cheese varieties; Provolone, Mozzarella, Mudaffara and Halloumi:An overview. Alex. J. Fd. Sci. and Technology.2 (2) :35- 41.

- AOAC 2000.Official methods of analysis (19th ed., vol. 2). Arlington, VA, USA: AOAC Int.

- Aslan I, Ozbek H, Calmasur O, Sahin F.2004. Toxicity of essential oil vapors to two greenhouse pests Tetranychusurticae Koch. andBemisiatabaciGenn. Ind. Crop.. 97(2):167-73.

- Ayar, A. 2002.Effect of some herb essential oils on lipolysis in white cheese.J.Food Lipids, 9 (3) : 225-237.

- Bozin B, Mimica-Dukic N, Simin N, Anackov G.2006.Characterization of the volatile composition of essential oils of some Lamiaceae spices and the antimicrobial and antioxidant activities of the entire oils. J. Agric. Food Chem. 54(5): $1822-8$.

- Burt, S. 2004. Essential oils: their antibacterial properties and potential applications in foods. International Journal of Food Microbiology, 94: 223-253.

- Costable, L.; Pauletti, M. S. and Hynes E. 2007. Proteolysis in Mozzarella cheeses manufactured by different industrial processes. J. Dairy Sci., 90:21032112.

- El-Kholy, W., El-Khalek, A.B.A., Mohamed, S.H.S., Fouad, M.T., Kassem, J.M. 2016.Tallaga cheese as a new functional dairy product. Am. J. Food Technol., 11(5): 182-192.

- El-Nawawy, M.A., El-Kenany, Y.M. \&Abd El- Ghaffar, E.A. 1998.Effect of Some herb Plants on the Use of Yoghurt Culture.Annals of agriculture Sci. 7th.Conf. Agric. Dev. Res. Fac. Agric. Ain Shams University of Cairo, Egypt.15-17 December.

- Foda, M. I.; El-Koly, W.I. and Seleet, L.F. 2006.Herbs as a way for improving quality and prolonging shelf life of soft cheese.Ann. Agric. Sci. AinSams Univ.,51:467-467. 
- Foda, M. I.; El-Sayed, M.A., Hassan, A.A; Rasmy, N.M. and El-Moghazy, M.M. 2008.Effect of spearmint essential oil on ripening of white cheese. 3rd Int. Conf. NRC,Cairo, 252-266.

- Gamal,A.M.Hassan,A.S.H.; El- Behairy,S.A. and Mohamed,IE.A. 2012.Impact of Zinc and Iron Salts Fortification of Buffalos milk on the dairy product. World Journal of Dairy\&Food Sciences 7 (1) 21-27.

- Kamaly, K. M. 1978.Studies on the effect of some plant flavours additives on Domiati cheese.M.Sc. Thesis, Monoufiea Univ., Egypt.

- Keeny, PG. 1971.Aguide to controlling oxidation in butter cream. Cited from Abd-Rabou.N.S.(1994). Production of some dietetic dairy products.Ph.D.Thesis.Ain Shams Univ., Egypt.

- Kresic, G., Herceg, Z., Lelas V., Jambrak, A. R. 2010. Consumers' behaviour and motives for selection of dairy beverages in Kvarner region: A pilot study. Mljekarstvo, 60, 50-58.

- Ling, E. R. 1963.A text-book of dairy chemistry, practical (3rd ed., vol. 2). London, England: Champan and Hall.

- Mehanna, A.S. Rashed, M.A. 1990. An attempt to improve the keeping quality of Tallaga cheese by using milk treated with carbon dioxide. Egypt. J. Dairy Sci., 18: 377-388.

- Mohanlal S, Parvathy R, Shalini V, Mohanan R, Helen A, Jayalekshmy A.2012. Chemical indices, Antioxidant activity and anti-inflammatory effect of extracts of the medicinal rice "Njavara" and staple varieties. J. Food Biochem. 36: 1-12.

- Omidbeigi R.2000. Production and processing of medicinal plants. Tehran: AstanGhodsRazavi . Vol. I. P. 99-104.

- Pappas, C. P., Kondly, E. Voustsinas, L. P., Mallatou, H. 1996.Effect of starter level, draining time and aging on the physicochemical, organoleptic and rheological properties of feta cheese. J. Soc. Dairy Technol.,49(3), 73-78.

- Pedreschi R, Cisneros-Zevallos L.2006.Antimutagenic and antioxidant properties of phenolic fractions from Andean purple corn (Zea mays L.). J. Agric. Food Chem. 54(13): 4557-67.

- SAS 1990. SAS user's guid/STAT Ver. 6.04, 4th ed. Cary, NC: SAS Inst. 
- Sawadogo WR, Maciuk A, Banzouzi JT, Champy P, Figadere B, Guissou IP, 2012. Mutagenic effect, Antioxidant and anticancer activities of six medicinal plants from Burkina Faso. Nat. Prod. Res. 26(6): 575-9.

- Scalbert A, Manach C, Remesy C, Morand C.2005. Dietary polyphenols and the prevention of diseases. Crit. Rev. Food Sci. Nutr. 45(4): 287-306.

- Shirazi MT, Gholami H, Kavoosi G Rowshan V, Tafsiry A. 2014.Chemical composition, antioxidant, antimicrobial and cytotoxic activities of Tagetesminuta and Ocimumbasilicum essential oils. Food science \& nutrition, 2:146-155.

- Simon JE, Chadwick AF, Craker LE.1984. The scientific literature on selected herbs, and aromatic and medicinal plants of the temperate zone. Archon Books: Hamden.

- Simon JE, Morales MR, Phippen WB, Vieira RF, Hao Z.1999. Basil: A source of aroma compounds and popular culinary and ornamental herb. In: Janick J, Simon JE, editors. Perspectives on New Crops and New Uses. ASHS Press: Alexandria. P. 499-505.

- Suppakul P, Miltz J, Sonneveld K, Bigger SW.2003.Antimicrobial properties of basil and its possible application in food packaging. J. Agric. Food Chem. 51(11): 3197-207.

- Tarakci, Z. and Kucukoner, E. 2006.Effect of different cultures on physicchemical and sensory properties of low-fat herby cheese. Food Science and Technology International, 12:423-428. 


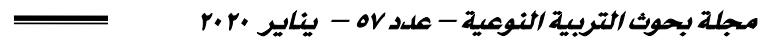

تأثير زيت الربحان الهلو علي إنسجام جبن الثلاجة كاهلة الدسم

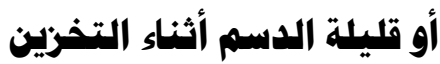

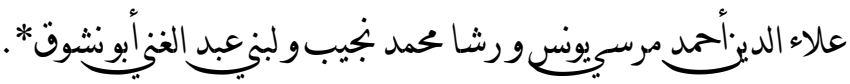

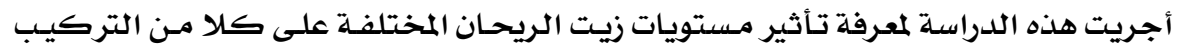

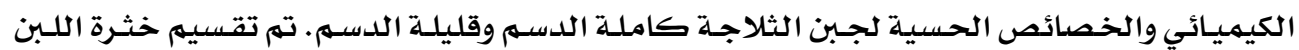

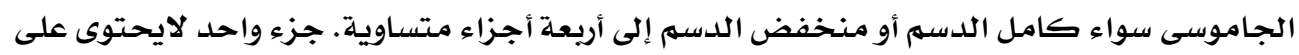

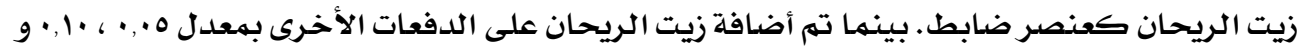

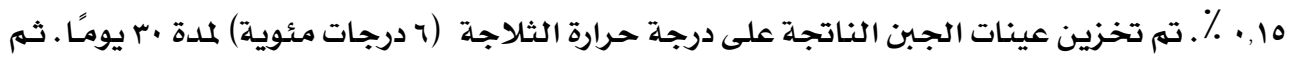

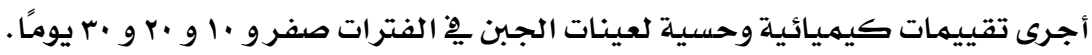

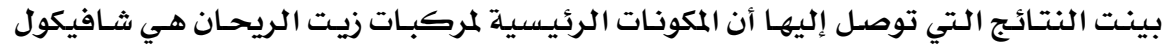

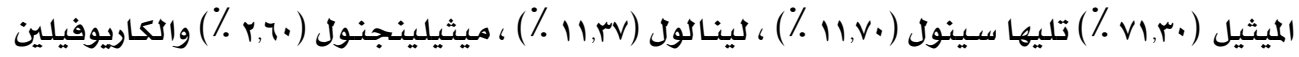

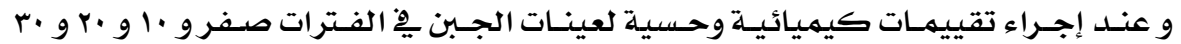

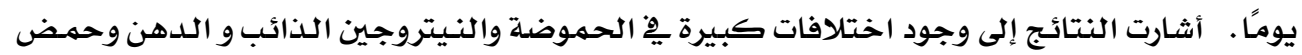

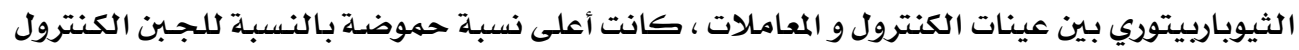

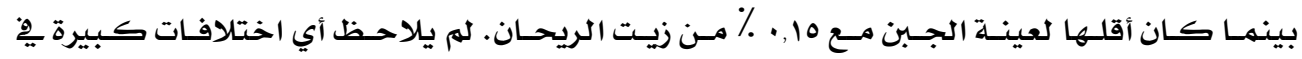

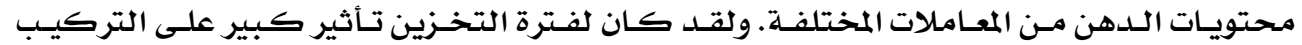

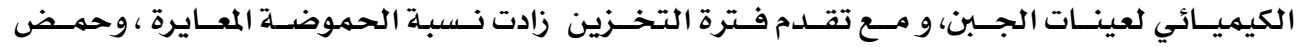

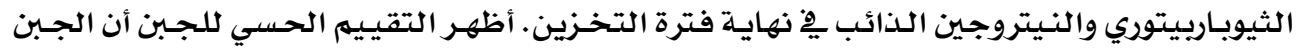

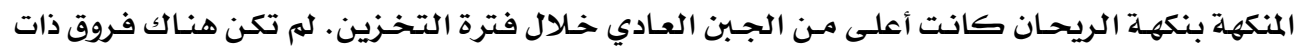

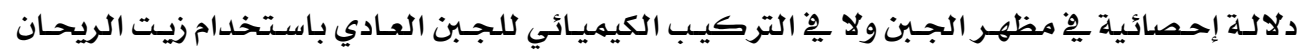
الحلو.

قسم الإقتصاد المنزلي - كلية التربية النوعية - جامعة اللمنصورة 